\title{
DETERMINATION OF 8-HYDROXY-2'DEOXYGUANOSINE IN URINE USING HPLC WITH ELECTROCHEMICAL DETECTION
}

\author{
Ana-Marija DOMIJAN and Maja PERAICA \\ Institute for Medical Research and Occupational Health \\ Zagreb, Croatia \\ Received in April 2008 \\ Accepted in October 2008
}

\begin{abstract}
Endogenous cell metabolism and different chemicals, drugs, ionising radiation, solar light, cigarette smoking, and air pollution can induce oxidative damage to DNA. Oxidative DNA damage is involved in the development of different diseases, aging, and cancer. Urine 8-hydroxy-2'deoxyguanosine (8-oxodG) is widely accepted as a biomarker of the "whole body" oxidative DNA damage. The aim of this study was to introduce a method for determination 8-oxodG in spot urine samples using high-performance liquid chromatography with electrochemical detection. In the tested range of $50 \mathrm{nmol} \mathrm{L}^{-1}$ to $400 \mathrm{nmol} \mathrm{L}^{-1}$, the calibration curve was linear $\left(r^{2}=0.9995\right)$ and the limit of detection was $3 \mathrm{nmol} \mathrm{L}^{-1}$. Concentrations of 8oxodG ranged between $3.0 \mathrm{nmol} \mathrm{L}^{-1}$ and $48.0 \mathrm{nmol} \mathrm{L}^{-1}$, which is in accordance with values reported for healthy individuals in other studies.
\end{abstract}

KEY WORDS: biomarker, free radicals, oxidative DNA damage, 8-oxodG

Chemicals, drugs, ionising radiation, solar light, cigarette smoking, and air pollution can increase the production of reactive oxygen species (ROS). ROS is a product of metabolism and causes damage to DNA and another macromolecules such as lipids and proteins. Oxidative DNA damage can lead to cancer, aging, and degenerative diseases (1). Although more than 20 different oxidative modifications of DNA bases have been identified, the major product of DNA oxidative damage is 8 -hydroxyguanine (8-oxoG) and its nucleoside 8-hydroxy-2'deoxyguanosine (8-oxodG). 8-oxodG has widely been accepted as a biomarker of DNA damage and cellular oxidative stress (2). Its appearance in urine is the consequence of DNA-repair mechanism in the cell. It is excreted via urine without metabolising any further. Thus, the urinary excretion of 8-oxodG reflects oxidative DNA damage and the "whole body" repair of DNA $(3,4)$.
The assessment of urine 8-oxodG involves a noninvasive method for the evaluation of oxidative DNA damage that could be correlated with exposure to ROS-inducing agents. 8-oxodG is stable in frozen urine for an extended period, and recent studies in humans reveal that the concentration of urine 8oxodG does not depend on nucleic acid in diet (5).

Since urine concentration of 8-oxodG is very low, and urine as such is a complex matrix, measurement of 8-oxodG in urine is an analytical challenge. Several methods for determination of 8-oxodG have been proposed such as gas chromatography - mass spectrometry, enzyme-linked immunosorbent assay, liquid chromatography - mass spectrometry, and high-performance capillary electrophoresis. As 8-oxodG oxidises readily, high performance liquid chromatography with electrochemical detection (HPLC-EC) can detect it even at low levels. The 
electrochemical detection of 8-oxodG has been shown to be three orders of magnitude more sensitive than UV detection (6).

The aim of this study was to develop a reliable HPLC-EC method for determination of 8-oxodG in a complex biological matrix such as urine. For this purpose, we tested different clean-up procedures, different mobile phase compositions, and analytical columns from different suppliers.

\section{MATERIALS AND METHODS}

\section{Chemicals}

8-oxodG standard was purchased from Sigma Chemicals (St. Louis, MO, USA). Potassium chloride, acetonitrile, and methanol were from Kemika (Zagreb, Croatia), and potassium dihydrogenphosphate and water were from Merck (Darmstadt, Germany). All chemicals were of pro analysis grade. Water, acetonitrile, and methanol used for mobile phase were of HPLC grade. Cartridges (Bond Elut C18, Bond Elut $\mathrm{C} 18 \mathrm{OH}$ and Bond Elut Certify) for solid phase extraction (SPE) were from Varian (Harbour City, CA, USA).

\section{Standard solution preparation}

Stock solution of 8-oxodG was prepared dissolving the 8-oxodG standard in purified water to give a final concentration of $100 \mu \mathrm{mol} \mathrm{L}^{-1}$. The concentration of the solution was checked spectrophotometrically at $293 \mathrm{nmol} \mathrm{L}{ }^{-1}$ using $\varepsilon_{293} 10300$. The stock solution was aliquoted and stored at $-20^{\circ} \mathrm{C}$. Working standards [(50-400) nmol L-1 $]$ were prepared in HPLC-grade water weekly and kept at $4{ }^{\circ} \mathrm{C}$.

\section{Apparatus}

We used a Varian ProStar 210 (Walnut Creek, CA, USA) isocratic pump (with pulse damper) connected to a Varian ProStar 370 electrochemical detector. HPLC separation was performed on the reversephase C18 column $150 \mathrm{~min} \times 4.6 \mathrm{~mm}$ with $5 \mu \mathrm{m}$ particle size, obtained from two different manufactures (Asahipak ODP-50 4D, Shodex, Kawasaki, Japan and Microsorb 100-5 BDS, Varian, Harbour City, CA, USA). Chromatographic data were recorded using Varian Star chromatography workstation 5.0 (Walnut Creek, CA, USA) software.

\section{Chromatographic conditions}

The mobile phase consisted of $50 \mathrm{mmol} \mathrm{L}^{-1}$ $\mathrm{KH}_{2} \mathrm{PO}_{4}, 2 \mathrm{mmol} \mathrm{L}^{-1} \mathrm{KCl}$, and $2.5 \%$ of acetonitrile and $1 \%$ of methanol (pH 4.45). Before use, mobile phase was filtered through a $0.22 \mu$ m cellulose acetate filter and degassed in ultrasonic bath for 30 minutes. Elution was in isocratic mode at the flow rate of $0.5 \mathrm{~mL} \mathrm{~min}^{-1}$, and $20 \mu \mathrm{L}$ of standard or sample was injected to the HPLC analytical column.

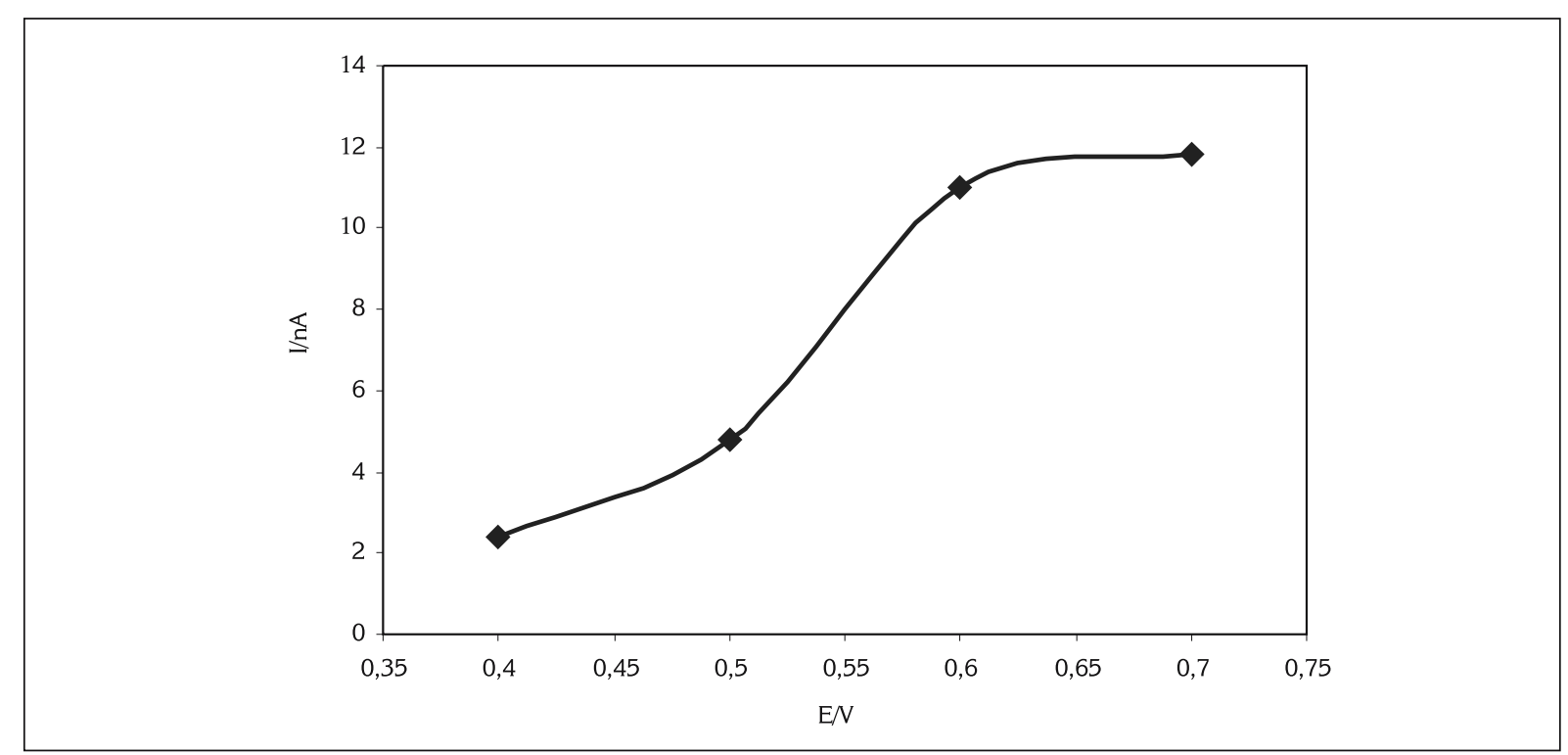

Figure 1 Hydrodynamic voltammogram of 8-oxodG obtained by running the same standard $\left(1 \mu\right.$ mol $\left.L^{-1}\right)$ at different working electrode potentials (mobile phase: $50 \mathrm{mmol} \mathrm{L}^{-1} \mathrm{KH}_{2} \mathrm{PO}_{4}, 2 \mathrm{mmol} \mathrm{L}^{-1} \mathrm{KCl}, 2.5 \%$ acetonitrile and $1 \%$ methanol, $\mathrm{pH} 4.45$; flow rate: $0.5 \mathrm{~mL} \mathrm{~min}{ }^{-1}$; injection volume: $20 \mu \mathrm{L})$. 


\section{Electrochemical conditions}

The electrochemical flow cell has a three-electrode configuration: a glassy carbon working electrode, an in situ $\mathrm{Ag} / \mathrm{AgCl}$ reference electrode (ISAAC), and a stainless steel auxiliary electrode. The ISAAC reference electrode needs less potential than the salt bridge $\mathrm{Ag} / \mathrm{AgCl}$ electrode, but requires mobile phase that contains $2 \mathrm{mmol} \mathrm{L}^{-1} \mathrm{KCl}$. The cell potential was set at $+0.6 \mathrm{~V}$. The analytical column and flow cell were kept in a Faraday-shielded oven compartment, and the temperature was set at $30^{\circ} \mathrm{C}$.

\section{Sample preparation}

Morning spot urine samples were obtained randomly from apparently healthy individuals $(\mathrm{N}=6)$. Different urine clean-up procedures on different cartridges were tested (2, 6-8).

Bond Elut C18 cartridges were used following the procedure of Samcova et al. (6) and Rebelo et al. (2). Following the first procedure, cartridges were preconditioned with $5 \mathrm{~mL}$ methanol, followed by $5 \mathrm{~mL}$ water. Two millilitres of the supernatant of centrifuged urine (1500 g, $10 \mathrm{~min}$.), one sample spiked with known concentration of 8-oxodG aqueous standard and one not, were applied to the cartridge under no excess of vacuum. The cartridge was then washed with $3 \mathrm{~mL}$ of $6 \%$ methanol and $6 \mathrm{~mL}$ of water. 8-oxodG was eluted from the cartridge with $10 \%$ acetonitrile. The eluted sample was evaporated to dryness under a stream of $\mathrm{N}_{2}$. Before injection to the HPLC, the sample was dissolved in $0.5 \mathrm{~mL}$ water. The same type of cartridges was used following the procedure of Rebelo et al. (2). Cartridges were preconditioned with $6 \mathrm{~mL}$ of methanol, followed by $3 \mathrm{~mL}$ of water and $6 \mathrm{~mL}$ of phosphate buffer ( $50 \mathrm{mmol} \mathrm{L}^{-1}, \mathrm{pH} \mathrm{6.1)}$. Three millilitres of the supernatant of centrifuged urine (one sample spiked with known concentration of 8-oxodG and one not), prepared as described above, were applied to the cartridges. Cartridges were washed with $3 \mathrm{~mL}$ of phosphate buffer $\left(50 \mathrm{mmol} \mathrm{L}^{-}\right.$ ${ }^{1}$, pH 6.1). 8-oxodG was eluted with $3 \mathrm{~mL}$ of $20 \%$ methanol in phosphate buffer ( $\left.50 \mathrm{mmol} \mathrm{L}^{-1}, \mathrm{pH} 6.1\right)$. Aliquots of the eluted solution were directly injected to the HPLC.

The next clean-up procedure was performed on Bond Elut $\mathrm{C} 18 \mathrm{OH}$ cartridges preconditioned with $10 \mathrm{~mL}$ methanol, followed by $10 \mathrm{~mL}$ of water (7). Urine samples were acidified ( $\mathrm{pH} 4-5$ ) and centrifuged as in previous procedures, and $2 \mathrm{~mL}$ of the supernatant of urine (one sample spiked with known 8-oxodG concentration and one not) were applied to cartridges. The cartridges were washed with $5 \mathrm{~mL}$ of water and 8-oxodG was eluted with $2 \mathrm{~mL} 30 \%$ methanol. Before injection to HPLC eluted sample was evaporated to dryness and dissolved in $0.5 \mathrm{~mL}$ of water.

The third type of cartridges, Bond Elute Certify, was tested for the clean-up of urine sample according to the Spinosa de Martinis and Pires Bicanchi method (8) with some modifications. The cartridges were preconditioned with $10 \mathrm{~mL}$ methanol, $5 \mathrm{~mL}$ water, and $10 \mathrm{~mL}$ phosphate buffer $\left(0.1 \mathrm{mmol} \mathrm{L}^{-1}, \mathrm{pH} 6.0\right)$. An aliquot of $2.0 \mathrm{~mL}$ of urine (one sample spiked

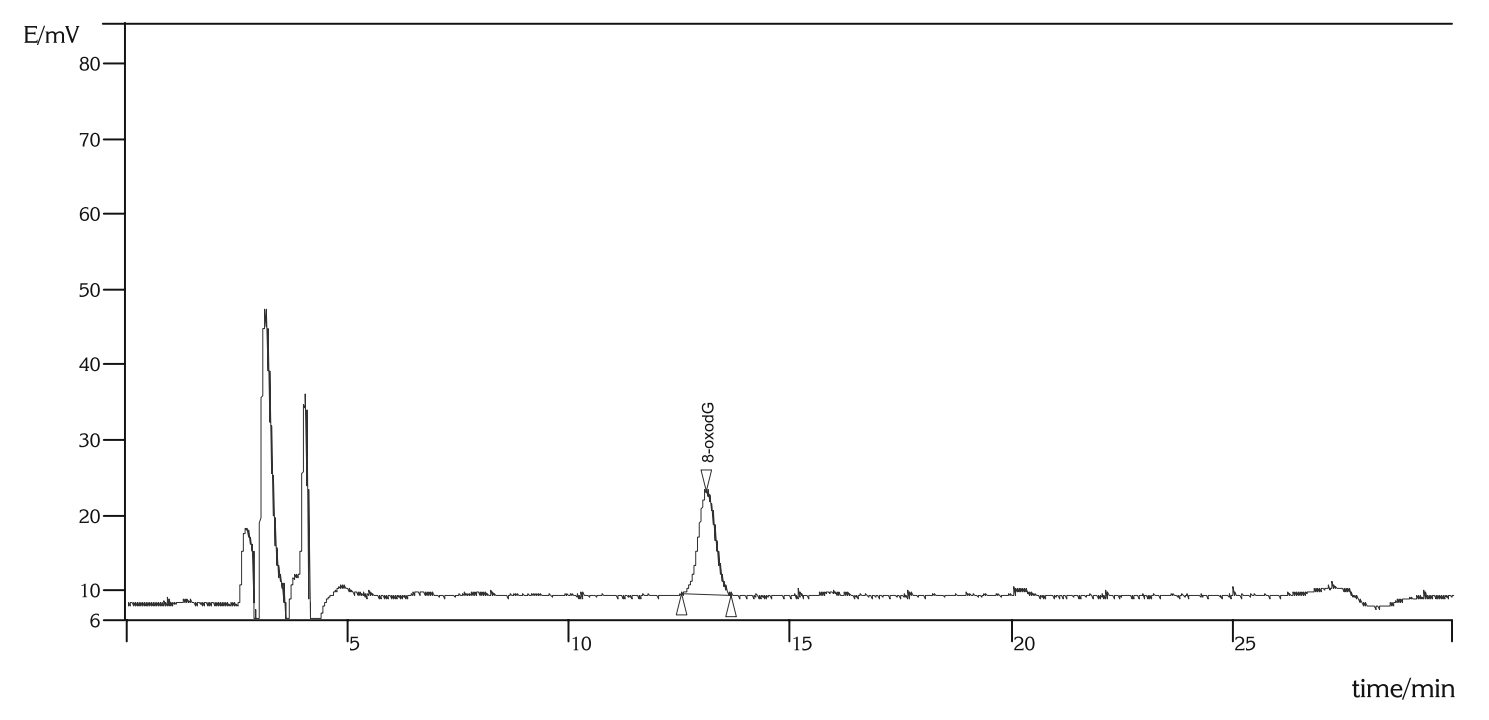

Figure 2 HPLC-EC chromatogram of a standard of $200 \mathrm{nmol} \mathrm{L}^{-1} 8$-oxodG (mobile phase: $50 \mathrm{mmol} \mathrm{L}^{-1} \mathrm{KH}_{2} \mathrm{PO}_{4}, 2 \mathrm{mmol} \mathrm{L}{ }^{-1} \mathrm{KCl}, 2.5 \%$ acetonitrile

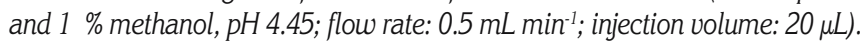


with known 8-oxodG concentration and one not) was applied to the cartridge. The cartridge was washed with $3 \mathrm{~mL}$ water and dried under full vacuum for 10 min. 8-oxodG was eluted with $1 \mathrm{~mL}$ phosphate buffer (0.1 $\mathrm{mmol} \mathrm{L}^{-1}, \mathrm{pH}$ 6.0). The elute was evaporated to dryness, and after dissolving in $0.5 \mathrm{~mL}$ of water, injected to the HPLC.

Urine 8-oxodG was quantified by measuring peakareas on the linear regression curve for aqueous standard solutions $\left(50 \mathrm{nmol} \mathrm{L}^{-1}, 100 \mathrm{nmol} \mathrm{L}^{-1}\right.$, $200 \mathrm{nmol} \mathrm{L}^{-1}$, and $\left.400 \mathrm{nmol} \mathrm{L}^{-1}\right)$.

\section{RESULTS AND DISCUSSION}

Literature is not conclusive about the importance of the $\mathrm{pH}$ of the mobile phase in 8-oxodG measurement. Most authors used acidic mobile phase $(\mathrm{pH}=3.5)$ $(6,9)$, while other reported that the tested $\mathrm{pH}$ range of 4.5-7 was not relevant for the retention time of 8-oxodG on the analytical column (C18) (2). We found that there was no difference in the retention time and in recovery (peak size) of 8-oxodG when we used mobile phases of either $\mathrm{pH} 4.45$ or 3.5. Experimental values for 8-oxodG pK are scarce, but some results indicating that 8-oxodG is neutral below $\mathrm{pH} 8$ may explain the independence of the retention time and recovery from the $\mathrm{pH}$ of the mobile phase. Although $\mathrm{pH}$ does not affect the retention time and peak size of 8-oxodG, methanol (the organic part of the mobile phase) shifts the retention time of the peak. An increase in methanol content also lowers the background current.

The best results were obtained with a mobile phase that consisted of $50 \mathrm{mmol} \mathrm{L}^{-1} \mathrm{KH}_{2} \mathrm{PO}_{4}, 2 \mathrm{mmol} \mathrm{L}^{-1}$ $\mathrm{KCl}, 2.5 \%$ acetonitrile, and $1 \%$ methanol, with final $\mathrm{pH}$ of 4.45. The flow rate was adjusted according literature data to $0.5 \mathrm{~mL} \mathrm{~min}^{-1}$.

To analyse urine 8-oxodG, we used the reversephase mode. As nucleotides are often too hydrophilic to be separated with standard (silica-based) C18 ODS columns, nucleosides are detected instead (10). We tested two $\mathrm{C} 18$ reverse-phase analytical columns from different suppliers. Asahipak ODP-50 4D column has a low-polarity, polymer-based packing material with octadecyl groups. With this column, separation was low and peaks tailed. Microsorb 100-5 BDS column is declared to minimise tailing for small charged molecules. Because of ionic interactions between charged compounds and charged silanols at the surface of the silica on a C18 column, the peaks of charged compounds are tailed. With this column the separation of the peaks was better.

Higher potential enhances electrochemical reaction and increases the analyte's signal, that is, sensitivity is greater, but so is interference. The choice of the working potential is a compromise between sensitivity, selectivity, and reproducibility. In order to find the optimal working potential for 8-oxodG, we made a hydrodynamic voltammogram (known as the I-E curve), which describes the currentvoltage relationship. We established the I-E curve by running several chromatograms of the same 8oxodG concentration $\left(1 \mu \mathrm{mol} \mathrm{L}^{-1}\right)$ at different working potentials $(E=+0.4 \mathrm{~V}$ to $+0.7 \mathrm{~V}$ ) (Figure 1). The optimal working potential was $+0.6 \mathrm{~V}$.

On the Microsorb 100-5 BDS column and mobile phase containing $50 \mathrm{mmol} \mathrm{L}^{-1} \mathrm{KH}_{2} \mathrm{PO}_{4}, 2 \mathrm{mmol} \mathrm{L}^{-1}$ $\mathrm{KCl}, 2.5 \%$ acetonitrile, and $1 \%$ methanol, with the flow rate of $0.5 \mathrm{~mL} \mathrm{~min}^{-1}$, the retention time of 8-oxodG was around 13 minutes (Figure 2). The calibration curve for calculating 8-oxodG concentrations was prepared from working standards in the concentration range from $50 \mathrm{nmol} \mathrm{L}^{-1}$ to $400 \mathrm{nmol} \mathrm{L}^{-1}$. The curve was linear $\left(r^{2}=0.9995\right)$, and the curve slope was $y=0.03 x \pm 1.76$. The limit of detection calculated by taking the average noise signal and adding three standard deviations of noise was $3 \mathrm{nmol} \mathrm{L}^{-1}$. Reproducibility (day-to-day precision) was below $5 \%$ R.S.D.

Most common cartridges used for urine clean-up are the hydrophobic, silica-based C18 cartridges, because they retain most organic analytes from aqueous matrices. In our study, three different cartridges for urine clean-up were tested.

Two different clean-up procedures on Bond Elut C18 $(2,6)$ did not sufficiently purify the sample for HPLC analysis, and some other compounds were co-eluted at the retention time of 8-oxodG. The third clean-up procedure was tested using the nonendcapped version of the C18 cartridge, that is, $\mathrm{C} 18 \mathrm{OH}$ (7). The results were similar even though producers declare that the non-endcapped version of the octadecyl-bonded phases is more active in the retention of the basic compounds and that the 150A intermediate pore size is good for intermediate-weight compounds. The third cartridge was an endcapped C8 column, which is usually used to desalt aqueous matrices for the analysis of small to intermediate molecules, but which we used to clean urine samples. A modified method of Spinosa de Martinis and Pires 
Bianchi for cleaning urine gave the best separation of peaks (8).

In our study, the calculated 8-oxodG concentrations in spot urine samples $(\mathrm{N}=6)$ collected from healthy individuals ranged between $3.0 \mathrm{nmol} \mathrm{L}^{-1}$ and $48.0 \mathrm{nmol} \mathrm{L}^{-1}$. Our results support another study reporting a range between $2.4 \mathrm{nmol} \mathrm{L}^{-1}$ and $93.3 \mathrm{nmol} \mathrm{L}^{-1}$ in urine of 60 healthy non-smokers (9). In most studies, using various methods, the reported values of 8-oxodG concentrations in urine were below $30 \mathrm{nmol} \mathrm{L}^{-1}$ (corresponding to $10 \mathrm{ng} \mathrm{mg}^{-1}$ of creatinine) (2).

Despite analytical difficulties associated with the clean-up, urine 8-oxodG measurement has the following advantages over the measurement of oxidative DNA damage in tissue: it is a non-invasive method, 8-oxodG is not artificially produced during isolation of DNA, and it is stable during urine storage and assay. The measurement of DNA base products excreted into the urine reflects well oxidative DNA damage in the whole organism.

\section{Acknowledgments}

This study received financial support from the Ministry of Science, Education, and Sports of the Republic of Croatia (Grant No. 0022-02221482142).

\section{REFERENCES}

1. Halliwell B. Why and how should we measure oxidative DNA damage in nutritional studies? How far we come? Am J Clin Nutr 2000;72:1082-7.
2. Rebelo IA, Piedade JAP, Oliveira-Brett AM. Development of an HPLC method with electrochemical detection of femtomoles of 8-oxo-7,8-dihydroguanine and 8-oxo7,8-dihydro-2'deoxyguanosine in the presence of uric acid. Talanta 2004;63:323-31.

3. Wu LL. Chiou C-C, Chang P-Y, Wu JT. Urinary 8-OHdG: a marker of oxidative stress to DNA and a risk factor for cancer, atherosclerosis and diabetics. Clin Chim Acta 2004;339:1-9.

4. Loft S, Poulsen HE. Estimation of oxidative DNA damage in man from urinary excretion of repair products. Acta Biochim Pol 1998;45:133-44.

5. Olinski R, Gackowski D, Foksinski M, Rozalski R, Roszkowski K, Jaruga R. Oxidative DNA damage: assessment of the role in carcinogenesis, stherosclerosis, and aquired immunodeficiency syndrome. Free Radic Biol Med 2002;33:192-200.

6. Samcova E, Marhol P, Opekar F, Langmaier J. Determination of urinary 8-hydroxy-2-deoxyguanosine in obese patients by HPLC with electrochemical detection. Anal Chim Acta 2004;516:107-10.

7. Xu GW, Yao QH, Weng QF, Su BL, Zhang X, Xiong $\mathrm{JH}$. Study of urinary 8-hydroxydeoxyguanosine as a biomarker of oxidative DNA damage in diabetic nephropathy patients. J Pharm Biomed Anal 2004;36:101-4.

8. Spinosa de Martinis B, Pires Bianchi ml. Methodology for urinary 8-hydroxy-2'-deoxyguanosine analysis by HPLC with electrochemical detection. Pharmacol Res 2002;46:129-31.

9. Germadnik D, Pilger A, Rüdiger HW. Assay for the determination of urinary 8-hydroxy-2'-deoxyguanosine by high-performance liquid chromatography with electrochemical detection. J Chromatogr B 1997;689:399-403.

10. Esaka Y, Inagaki S, Goto M. Separation procedures capable of revealing DNA adducts. J Chromatogr B 2003;797:321-9. 


\section{Sažetak \\ ODREĐIVANJE 8-HIDROKSI-2'DEOKSIGVANOZINA U MOKRAĆI S POMOĆU HPLC-A S ELEKTROKEMIJSKIM DETEKTOROM}

Do oksidacijskog oštećenja DNA dolazi zbog metabolizma unutar stanice, kao i djelovanjem različitih lijekova, ionizirajućeg zračenja, sunčevih zraka, pušenja i onečišćenja zraka. Dokazano je da je oksidacijsko oštećenje DNA povezano s nastankom različith degenerativnih bolesti, starenjem i nastankom malignih bolesti. Općenito je prihvaćeno da je nastanak 8-hidroksi-2'deoksigvanozina (8-oksodG) dobar pokazatelj oksidacijskog oštećenja DNA. Koncentracija 8-oksodG u stanicama pokazatelj je oksidacijskog oštećenja u tkivima, a njegova koncentracija u mokraći pokazatelj je oksidacijskog oštećenja u cijelom organizmu. Cilj ovog rada bio je uvesti metodu određivanja 8-oksodG u mokraći uz pomoć tekućinske kromatografije visoke djelotvornosti (HPLC) s elektrokemijskim detektorom. U ispitivanom rasponu koncentracija ( $50 \mathrm{nmol} \mathrm{L}{ }^{-1}$ do $\left.400 \mathrm{nmol} \mathrm{L}^{-1}\right)$ baždarna krivulja bila je linearna $\left(\mathrm{r}^{2}=0.9995\right)$, a granica detekcije bila je $3 \mathrm{nmol} \mathrm{L}^{-1}$. Raspon koncentracija 8-oksodG u uzorcima mokraće zdravih ispitanika bio je $3.0 \mathrm{nmol} \mathrm{L}^{-1}$ do $48.0 \mathrm{nmol} \mathrm{L}^{-1}$, što odgovara vrijednostima u zdravim ispitanicima u drugim istraživanjima.

KLJUČNE RIJEČI: biomarker, oksidacijsko oštećenje DNA, 8-oksodG, slobodni radikali

CORRESPONDING AUTHOR:

Ana-Marija Domijan, PhD

Institute for Medical Research and Occupational Health

P. O. Box 291, HR-10090 Zagreb, Croatia

E-mail: adomijan@imi.hr 